\title{
Procedure for Regional Property Removal at Badan Pengelolaan Keuangan dan Aset Daerah (BPKAD) Kabupaten Serang
}

\author{
Siti Agustina Rahayu ${ }^{1^{*}}$ \\ ${ }^{1}$ University of Sultan Ageng Tirtayasa, Indonesia \\ sitiagustinarahayu21@gmail.com ${ }^{1 *}$
}

Keywords : Elimination Procedures, Regional Assets, State Property

\begin{abstract}
:
The objectives of this study are: to find out the procedure for the elimination of Regional Property (BMD) at the Regional Financial and Asset Management Agency (BPKAD) Serang Regency, to find out what obstacles occur in the implementation of the elimination of Regional Property (BMD) at the Regional Asset Management Agency. Regional Finance and Assets (BPKAD) Serang Regency. The results of the study indicate that the abolition of State Property has been carried out according to the procedures and the obstacles faced and overcome.
\end{abstract}




\section{Introduction}

According to Law Number 32 of 2004 which has been updated to Law Number 23 of 2014 concerning Regional Government, it is stated that regional autonomy is the right, authority and obligation of autonomous regions to regulate and manage their own government affairs and the interests of the local community in accordance with laws and regulations. invitation. In its implementation, regional autonomy must be empowered by means of the central government providing full support to the regions to explore and utilize existing resources in their regions.

By being given the authority to manage government affairs and the interests of the community on their own, this makes an excellent opportunity for the local government to provide evidence that the region is capable of carrying out the authority that is the right of the region. The provisions and the will to implement the regional government will determine the progress or not of a region, without violating the provisions of the applicable laws, regional governments are free to create and express their regions in the context of developing their own regions.

The regional government must provide maximum efforts so that the implementation of the financial management authority that has been given by the central government can be carried out as well as possible by the regional government. This is a demand from the implementation of regional autonomy, namely as an effort to achieve good corporate governance. The basic principles of implementing good corporate governance are fairness (fairness and equality), transparency (transparency), accountability (accountability), responsibility (responsibility) and independence (independence). The implementation of good corporate governance is carried out using internationally accepted principles. These basic principles are expected to be a reference for regulators (government) in developing a framework for implementing good corporate governance. (Nuristianti at all:2018)

Planning, implementation, administration, reporting, accountability and supervision of regional finances are all activities of regional financial management. This must be implemented in order to form good governance in the field of regional financial management. Regional finance is all forms of wealth related to all rights and obligations that can be valued in money in the context of government administration.

To be able to prove whether regional financial management is said to be good, that is by looking at the quality of the results of regional financial reports that have been properly audited by the Supreme Audit Agency (BPK) by obtaining an unqualified opinion. However, there are still many results of examinations of government financial statements that have not received an unqualified opinion, one of the causes of the lack of quality of regional financial reports is the management of regional assets. Regional assets or regional property are not only managed in the administrative process, but also must pay attention to efficiency, effectiveness, and create added value in the management of regional assets or property. (Sapjeriani:2018)

The regional government is given full authority by the central government in regulating the affairs of the management of regional property, in which there are activities for the 
elimination of regional property. The abolition of regional property is one form of a proper governance process, in which the administration of government will be good, polite, fair and free from violations and also acts of abuse of authority if the general principles of proper governance (AAUPL) can be understood and also made into as the basis for proper governance procedures. (Rahman: 2016)

The city or district government already has an integrated central information system in terms of managing goods and assets belonging to the region. The name of the system is the Regional Goods and Assets Management Information System, which is abbreviated as SIMBADA. The Regional Goods and Assets Management Information System or SIMBADA is an application system in the context of managing the inventory of regionally owned goods by displaying standard report forms and formats that are standardized and easy to implement. The purpose of this SIMBADA application is to provide convenience for agencies to improve performance quickly, namely regarding the inventory data of goods and assets owned by the government which are made based on the Minister of Home Affairs Regulation No. 17 of 2007.

In connection with Government Regulation no. 18 of 2016 concerning Regional Apparatuses, in 2017 the Regional Financial and Asset Management Agency (BPKAD) of Serang Regency was formed which consists of five (5) fields, namely, the Budget Sector, Regional Assets Sector, Accounting Sector, Secretariat Sector, and Treasury Sector. The Regional Financial and Asset Management Agency (BPKAD) of Serang Regency is a government agency tasked with carrying out regional government affairs in the field of Regional Financial and Asset Management based on the principles of regional autonomy and assistance tasks.

In carrying out their duties, each field has several sub-fields to assist the head of the field in carrying out their duties and functions properly. The main tasks and functions of each sector and sub-sector have been regulated by the Serang Regent Regulation Number 87 of 2018 concerning the Main Duties and Functions of the Regional Financial and Asset Management Agency of Serang Regency.

Then to support the management of regional assets, several regulations have been drafted including the Regent's Regulation (Perbup) No. 86 of 2009 concerning Regional Property Management Systems and Procedures, and Grant Mechanisms. The abolition of regional property (BMD) is carried out by the Regional Financial and Asset Management Agency (BPKAD) of Serang Regency, as an assistant to the goods manager. All SKPD (Regional Apparatus Work Units) are given the authority to apply for the abolition of regional property, both goods users and goods users through delegates (representatives).

Procedures are clear and detailed documents to describe the methods used in implementing and implementing organizational policies and activities as set out in the guidelines. Basically, procedures are written instructions as guidelines in completing a routine or repetitive task in an effective and efficient manner, to avoid variations or deviations that can affect the overall performance of the organization. (Soemohadiwidjojo, 2014: 90).

Based on Government Accounting Standards Statement (PSAP) No. 7, assets in the government sector are economic resources controlled and/or owned by the government as a result of past events and from which future economic and/or social benefits are expected to 
be obtained, both by the government and the community, and can be measured in units of money, including non-financial resources necessary for the provision of services to the general public and resources maintained for historical and cultural reasons. Assets in the government sector are divided into current assets, long-term investments, fixed assets and other assets. One type of asset that is significant in the government's balance sheet is fixed assets.

Fixed assets are tangible assets that have a useful life of more than 12 (twelve) months to be used, or intended to be used, in government activities or utilized by the general public. Furthermore, it is mentioned that fixed assets are often a major part of government assets, and are therefore significant in the presentation of the balance sheet. Regional assets are an important element in encouraging economic growth in the area concerned, so all matters relating to assets must be monitored on a regular basis. (Erlina at all, 2015:245)

Regional property (BMD) is all goods purchased or obtained at the expense of the Regional Revenue and Expenditure Budget (APBD) or derived from other legitimate acquisitions. Regional property has the possibility for deletion or transfer which must be carried out based on the applicable law and ratified by the Regional Head as the highest leader in the Management of Regional Property.

Based on the Regulation of the Minister of Home Affairs Number 19 of 2016, Management of Regional Property is the entire activity that includes planning needs and budgeting, procurement, use, utilization, security and maintenance, assessment, transfer, destruction, elimination, administration and guidance, supervision and control . One of the management of regional property is elimination. To manage regional property in an area, a strong legal basis is needed so that in its implementation it does not violate existing laws and is in accordance with applicable regulations. One of the regulations made for the management of regional property is the Minister of Home Affairs Regulation Number 19 of 2016. This regulation is made to be able to regulate the management of regional property properly,

According to the Regulation of the Minister of Home Affairs Number 19 of 2016 Article 1 number 46, it is stated that deletion is the act of removing regional property from the list of goods by issuing a decision from the competent authority to release goods managers, goods users and/or goods users from administrative and physical responsibilities. for the goods in their possession. Deletion is the final process of the life journey of regional property, because deletion is the act of removing regional property from the list of regional property in that area.

Elimination of regional property (BMD) is one of the follow-up processes of regional property management based on the Minister of Home Affairs Regulation Number 19 of 2016, with the aim of freeing regional property management (BMD) and to remove regional property that has met the criteria to carry out an action to remove from administrative responsibility for physical goods that are in the management of the treasurer of goods or goods management or goods users based on applicable regulations.

The problem regarding the abolition of regional property (BMD) in regional governments is a problem that cannot be taken lightly, because if there are regional property assets that are under the management and control of an SKPD (Regional Apparatus Work Unit) or what is now called OPD (Regional Apparatus Organization) ) does not pay attention to the problem of 
the abolition of the regional property, which is because the goods are no longer suitable for use, are damaged and are not used, then it is very possible that a condition will arise in which the regional property that has not been written off cannot be used or does not even contribute to the operational activities in the work of the government.

In this case indirectly the regional property will only burden maintenance costs due to the procurement of regional property, and for its management there is still a budget regarding maintenance costs for regional property because the goods are not removed from the list of regional property. The reason for the abolition of regional property is to save the budget for government activities, reduce the place/warehouse for storage of regional property that is no longer used which will fill the place due to the accumulation of goods, in this case it would be better if the goods were removed. Prior to the abolition of regional property, there are several reasons why regional property is abolished, namely the transfer of regional property,

Regional property that has been damaged, is not suitable for use and is also not utilized through transfer, either through sales, exchange, grants, and also local government capital participation will only increase maintenance costs and require special attention to avoid the accumulation of regional property. This is the reason why there needs to be an action to remove the property belonging to the region from the list of regional property. However, in other conditions, it is the opposite, namely regional property that has been registered and an act of deletion is to be carried out, but the physical condition of the goods does not appear good because it is heavily damaged or due to other reasons.

This is what makes the writer interested in knowing more about the procedure for the elimination of regional property at the Regional Financial and Asset Management Agency (BPKAD) Serang Regency. Based on this background, the authors are interested in choosing the title of the final project report with the title "PROCEDURE FOR REGIONAL PROPERTY ELIMINATION IN THE REGIONAL FINANCIAL AND ASSETS MANAGEMENT AGENCY (BPKAD) SERANG REGENCY"

\section{Research Method}

The method used in this final report is descriptive. According to Sugiyono, (2012:2) the definition of research method is a method in examining the status of human groups, an object, a condition, a research system, as for a class of events in the present. The purpose of this descriptive research is to make a systematic, factual and accurate description, picture, or painting of the facts, characteristics and relationships between the phenomena being investigated. In a broader sense of research methods outside of historical and experimental methods, and more generally often referred to as survey methods.

\section{Results and Discussion}

\section{Procedure for the elimination of Regional Property (BMD)}

Based on the results of research from industrial internship activities that have been carried out at the Regional Financial and Asset Management Agency (BPKAD) of Serang Regency, namely regarding the procedure for the elimination of regional property 
(BMD), it is appropriate and has implemented the current regulations in Indonesia, namely the Regulation of the Minister of Home Affairs. Republic of Indonesia Number 19 of 2016 concerning Guidelines for the Management of Regional Property. Based on the Regulation of the Minister of Home Affairs Number 19 of 2016 explains in more detail the implementation of the abolition of Regional Property on Goods Users and/or Proxy of Goods Users in accordance with the cause.According to the Regulation of the Minister of Home Affairs Number 19 of 2016 Article 432 paragraph (3) Elimination from the List of Regional Property, carried out in the event that the abolition occurs due to the transfer of regional property, a court decision that has permanent legal force and there are no other legal remedies, carrying out the provisions of the law, destruction, and another reason.

\section{Transfer of regional property}

\section{Article 439}

1) Deletion due to the transfer of regional property is carried out by the Property User/Proxy of Property User

2) The deletion is carried out after the Property Manager issues a decision on the abolition of regional property.

3) The decision on the abolition of regional property within a maximum period of 1 (one) month is issued by the Property Manager as of the date of the Handover Certificate (BAST).

4) The decision on the abolition of regional property due to the transfer of regional property shall be submitted to the Property User accompanied by:

a. Minutes of Auction and Minutes of Handover (BAST), in the event that the transfer is carried out in the form of auction sales.

b. Minutes of Handover (BAST), in the event that the transfer is carried out in the form of sales without auction, exchange, and local government capital participation; and

c. Minutes of Handover and the manuscript of the grant, in the event that the transfer is carried out in the form of a grant.

5) The Property User submits a write-off report to the Governor/Regent/Mayor by attaching:

a. Deletion Decision; and

b. Minutes of Handover (BAST), Minutes of Auction, and Manuscripts of Grants.

1) Based on the deletion decision, the Property Manager removes regional property from the Regional Property List.

2. Court decisions that have obtained permanent legal force and there are no other legal remedies.

Article 441 
1) Elimination due to a court decision that has obtained permanent legal force and there are no other legal remedies carried out by the Property User/Proxy of the Goods User.

2) The Property User submits an application for the abolition of regional property to the Property Manager which at least contains:

a. Considerations and reasons for deletion; and

b. Regional property data requested for deletion include the year of acquisition, item code, register code, item name, type, identity, condition, location, book value, and/or acquisition value.

3) An application for the abolition of regional property shall at least be accompanied by:

a. A copy/photocopy of a court decision that has been legalized/ratified by an authorized official; and

b. Photocopies of ownership documents or equivalent documents.

4) Property Manager conducts research on the request for the removal of regional property from the Property User.

5) The research referred to includes:

a. Research data and documents belonging to the region;

b. Research on the content of court decisions related to regional property as objects of court decisions that have obtained permanent legal force and there are no other legal remedies; and

c. Field research (on site visit), if needed.

6) Field research is carried out to ensure the suitability of regional property which is the object of a court decision and regional property which is the object of a request for abolition.

7) Based on the results of the research, the Property Manager submits an application for approval to the Governor/Regent/Mayor.

\section{Article 442}

1) If the application for the removal of regional property is not approved, the Governor/Regent/Mayor through the Property Manager shall notify the Property User accompanied by reasons.

2) If the application for the abolition of regional property is approved, the Governor/Regent/Mayor issues an approval letter for the abolition of regional property.

1) The approval letter for the abolition of regional property as referred to in paragraph (2) contains data on regionally owned goods that are approved to be abolished, including the goods code, register code, name of the goods, year of acquisition, technical specifications/identity, condition of goods, amount, acquisition value, book value for regional property that can be depreciated, and the obligation of the Property User to report the implementation of the write-off to the Governor/Regent/Mayor. 


\section{Article 443}

1) Based on the approval of the Governor/Regent/Mayor as referred to in Article 422 paragraph (2), the Property Manager issues a decision on the removal of the goods.

2) The deletion decision becomes the basis for the Property User/Proxy of the Property User to delete regional property from the User's Goods List and/or User's Authorized Property List.

3) The decision on the abolition of regional property in no later than 1 (one) month is issued by the Property Manager as of the date of approval for the removal of regional property from the Governor/Regent/Mayor.

4) Property Users report the deletion to the Governor/Regent/Mayor by attaching a decision on the abolition of regional property.

5) Based on the deletion decision, the Property Manager removes regional property from the Regional Property List.

The abolition is carried out because of a court decision that has obtained permanent legal force and there are no other legal remedies.

\section{Carry out the provisions of laws and regulations}

\section{Article 446}

1) The abolition due to implementing the provisions of the legislation begins with the submission of an application for the elimination of regional property by the Property User to the Governor/Regent/Mayor through the Property Manager.

2) The said application shall at least contain:

a. Considerations and reasons for deletion; and

b. Regional property data requested for deletion, which at least includes year of acquisition, item code, register code, name of item, type, identity, condition, location, book value, and/or acquisition value.

3) Property Manager conducts research on the request for the removal of regional property from the Property User.

4) Based on the research, the Property Manager submits an application for approval to the Governor/Regent/Mayor.

\section{Article 447}

1) If the Governor/Regent/Mayor approves the application as referred to in Article 446 paragraph (4), the Governor/Regent/Mayor issues an approval letter for deletion.

2) The letter of approval for the abolition of regional property shall at least contain:

a. Regional property data approved for deletion, which at least includes year of acquisition, item code, register code, item name, technical specification/identity, type, condition, amount, book value, and/or acquisition value; and 
b. The obligation of the Property User to report the implementation of the write-off to the Governor/Regent/Mayor.

3) Based on the approval of the Governor/Regent/Mayor, the Property User shall delete regional property from the List of Property Users and/or List of Property Authorized by the User based on the decision to remove the Property Manager.

4) The decision on the abolition of regional property is issued no later than 1 (one) month by the Property Manager from the date of approval from the Governor/Regent/Mayor.

\section{Article 448}

1) The Property User reports the deletion of regional property to the Governor/Regent/Mayor, by attaching the deletion decision issued by the Property Manager.

2) Based on the deletion decision, the Property Manager removes regional property from the Regional Property List.

\section{4. extermination}

\section{Article 450}

1) Elimination of regional property due to destruction of the Property User by the Property User/Proxy of the Property User.

2) The abolition of regional property is carried out after the Property Manager issues a decision on the abolition of regional property.

3) The decision on the abolition of regional property is issued by the Property Manager no later than 1 (one) month from the date of the official report on the destruction.

4) The Goods User submits a report on the deletion to be submitted to the Governor/Regent/Mayor by attaching a decision on the deletion and an official report on the destruction as referred to in paragraph (3).

5) Based on the abolition decision, the Property Manager shall abolish regional property in the Regional Property List.

\section{Another reason}

\section{Article 452}

1) Deletion due to other reasons is carried out by the Property User/Proxy of the Goods User.

2) The Property User submits an application for the abolition of regional property to the Governor/Regent/Mayor through the Property Manager, which at least contains:

a. Considerations and reasons for deletion; and

b. Regional property data requested for deletion include the year of acquisition, item code, register code, item name, type, identity, condition, location, book value, and/or acquisition value. 
3) An application for the abolition of regional property can be submitted for the following reasons:

a. Lost due to theft.

b. Burns, shrinks, evaporates, melts, expires, dies for animals/fish/plants; or

c. Force majeure.

\section{Article 453}

1) An application for the abolition of regional property on the grounds that it is lost due to theft must be accompanied by:

a. Certificate from the Police; and

b. Statement letter from the Goods User/Proxy of the Goods User which at least contains:

a. Goods User Identity/Proxy of Goods User.

b. A statement regarding the truth of the application and the property of the area is lost due to theft and cannot be found; and

c. A statement if later evidence is found that the deletion of the regional property in question is due to an element of negligence and/or intentional negligence on the part of the official who uses/in charge of the regional property/goods manager, then it is possible that the person concerned will be subject to sanctions in accordance with the provisions of the legislation. -invitation.

2) Applications for the abolition of regional property on the grounds of burning, shrinking, evaporating, melting, expired, dead for animals/fish/plants must be accompanied by:

a. Goods User Identity/Proxy of Goods User.

b. Statement from the Property User/Proxy of the Property User regarding the truth of the submitted application.

c. A statement from the Property User/Proxy of the Property User that the regional property has burned, shrunk, evaporated, melted, expired, died for animals/fish/plants; and

d. The statement letter is attached with the results of the inspection/research report.

3) The application for the abolition of regional property by reason of force majeure must be accompanied by:

a. Certificate from the competent authority:

a. Regarding the occurrence of force majeure; or

b. Regarding the current condition of the goods due to force majeure; and

b. A statement that regional property has been affected by force majeure from the Property User/Proxy of the Property User. 


\section{Article 454}

1) Property Manager conducts research on the request for the removal of regional property from the Property User.

2) The research referred to includes:

a. Examine the feasibility of the consideration and reasons for the request for deletion;

b. Research on administrative data at least on item code, register code, item name, year of acquisition, specification/identity of regional property, determination of use status, proof of ownership for regional property which must be accompanied by proof of ownership, book value, and/or acquisition value; and

c. Physical examination of the request for deletion for reasons if necessary.

3) Based on the results of the research, the Property Manager submits an application for approval to the Governor/Regent/Mayor for the elimination of regional property for other reasons.

\section{Article 455}

2) If the request for removal as referred to in Article 452 paragraph (3) is not approved, the Governor/Regent/Mayor shall notify the Property User through the Property Manager accompanied by reasons.

3) If the request for elimination as referred to in Article 452 paragraph (3) is approved the Governor/Regent/Mayor issues a letter of approval for the abolition of regional property.

4) The approval letter for the abolition of regional property contains data on regionally owned goods that are approved to be abolished, which at least includes the goods code, register code, name of the goods, year of acquisition, technical specifications/identity, condition of goods, amount, acquisition value, book value for goods. belonging to the area that can be depreciated, and the obligation of the Property User to report the implementation of the write-off to the Governor/Regent/Mayor.

5) Based on the approval of the Governor/Regent/Mayor, the Property Manager shall make a decision to remove it no later than 1 (one) month from the date of approval.

6) Property User shall delete regional property from the User Goods List and/or User Authorized Property List based on the Deletion Decision.

The Property User submits a report on the abolition of the property to the Governor/Regent/Mayor by attaching a decision on the abolition of regional property. Based on the deletion decision, the Property Manager removes regional property from the Regional Property List.

\section{Obstacles during the process of implementing the elimination of Regional Property (BMD)}


The general obstacles experienced by the Regional Financial and Asset Management Agency (BPKAD) of Serang Regency in implementing the abolition of regional property are:

a. Goods that are registered for deletion actions but the goods do not have a physical or physical form on the goods.

Constraints that are often found are goods registered for an act of deletion but when a survey is carried out on the form or condition of the property belonging to the area, this usually occurs because the goods are lost so that the goods that were originally there become non-existent which causes a discrepancy between existing data with facts. Examples of regional property that often occur are vehicles and laptops.

Minister of Home Affairs Regulation No. 19 of 2016 states that one of the reasons that causes regional property to be abolished in Article 432 paragraph (3) is another reason. Another reasonare causes that are normally considered reasonable to be the cause of elimination, such as loss due to theft, fire, shrinkage, evaporation, melting, expiration, death, and as a result of force majeure.

An application for the abolition of regional property on the grounds that it is lost due to theft must be accompanied by:

a. Certificate from the Police; and

b. Statement letter from the Goods User/Proxy of the Goods User which at least contains:

1) Goods User Identity/Proxy of Goods User.

2) A statement regarding the truth of the application and the property of the area is lost due to theft and cannot be found; and

3) A statement if later evidence is found that the deletion of the regional property in question is due to an element of negligence and/or intentional negligence on the part of the official who uses/in charge of the regional property/goods manager, then it is possible that the person concerned will be subject to sanctions in accordance with the provisions of the legislation. -invitation.

a. Regional property (BMD) in the form of vehicles if it cannot be used through sales and grants, the goods are destroyed. One way to destroy vehicles is to drown them. However, this method has a long procedure because it cannot be done arbitrarily, there is a separate method of extermination by drowning. Submerging this vehicle must know where the goods will be disposed of, the location of the depth of the sea so that the goods can be disposed of, and must also have a permit. However, this method of extermination rarely occurs in the Regional Financial and Asset Management Agency (BPKAD) of Serang Regency. 


\section{Conclusion}

Based on the results of research and discussion that has been carried out by the author, it can be concluded that in general the procedures for implementing the abolition of regional property and also the obstacles that occur during the process of implementing the abolition of regional property are as follows:

1. The general procedure for the elimination of regional property is:

a. OPD The person concerned will attach a letter regarding the Application for Asset Elimination addressed to the Regional Secretary as the manager of the goods and then a copy to the Regional Financial and Asset Management Agency (BPKAD) of Serang Regency as the assistant to the goods manager.

b. BPKAD will re-inventory the items that want to be abolished.

c. The Serang Regency BPKAD has a removal team formed according to the decision of the Serang Regency Regent to survey the OPD regarding the items that want to be removed whether the items submitted are in accordance with the existing physical.

d. After conducting a survey, the Serang Regency BPKAD will determine whether the goods registered by the OPD will be transferred or destroyed, and will be deleted through this action.

e. The Serang Regency BPKAD records the items that have been taken action and the data will be submitted to the Serang Regency Regent, and asks for an approval letter for the removal of Regional Property (BMD) along with evidence in the form of photos, a statement from the OPD head stating the item is no longer suitable for use, and details of the items to be written off to the Regent.

f. After the Regent of Serang Regency approves the abolition of the proposed Regional Property (BMD), the BPKAD will provide the letter to the legal department so that a Decree of the Regent of Serang Regency is made regarding the abolition of Regional Property (BMD).

g. Based on the abolition decision, the Property Manager shall abolish regional property in the Regional Property List.

2. The general obstacles experienced by the Regional Financial and Asset Management Agency (BPKAD) of Serang Regency in implementing the abolition of regional property are:

a. Goods that are registered for deletion actions but the goods do not have a physical or physical form on the goods.

b. Regional property (BMD) in the form of vehicles if it cannot be used through sales and grants, the goods are destroyed. One way to destroy vehicles is to drown them. However, this method has a long procedure because it cannot be done arbitrarily, there is a separate method of extermination by drowning. Submerging this vehicle must know where the goods will be disposed of, the location of the depth of the sea so that the goods can be disposed of, and must also have a permit. However, this method of extermination rarely occurs in the Regional Financial and Asset Management Agency (BPKAD) of Serang Regency. 
The writer realizes that the writing of this final project is still far from perfect, with the writer's knowledge which is still limited. So the author will try to provide suggestions that are expected to be useful for the Agency. Some suggestions that the author will convey are as follows:

1. To reduce errors that occur in the implementation of the elimination of regional property, it is important to carry out inspections and supervision of the implementation procedures for the elimination of regional property.

2. To ensure that supervision is carried out properly, internal control should be carried out regularly and in a planned manner.

Especially in the area of assets, the Regional Financial and Asset Management Agency (BPKAD) of Serang Regency should increase its human resources in order to ease the work in managing regional assets in Serang Regency.

Suggestions from the author in carrying out the billing process must be more thorough and the process must be made easier so that there are no more mistakes, rounding up in making it easier to calculate salaries must be in accordance with the policies set. In addition, in future research, continuous research can be carried out on the same object and conducting research on different objects.

\section{Acknowledgment}

Acknowledgments are conveyed to the Diploma Three Accounting Study Program, Faculty of Economics and Business, University of Sultan Ageng Tirtayasa.

\section{References}

Erlina, Rambe, Omar, Sakti, Rasdianto. 2015. Accrual-Based Regional Financial Accounting Based on PP No. 71 of 2010 and Permendagri No. 64 of 2013. Jakarta: Salemba Empat.

Nuristianti, Eka, Wiwied. et al. 2018. Good Corporate Governance. Semarang. (https://www.academia.edu/36295089/Makalah Good Corporate Governance), (accessed March 10, 2020 at 19:08)

Regulation of the Minister of Home Affairs of the Republic of Indonesia Number 19 of 2016 concerning Guidelines for the Management of Regional Property.

Rahman, Muhammad, Aulia. 2016. Implementation of the Elimination of Regional Property in the Office of Building and Regional Assets of Yogyakarta City in 2015.

(http://digilib.uin-suka.ac.id/23946/1/12340057 BAB-I IV-or-V DAFTARPUSTAKA.pdf), (accessed February 18, 2020 at 3:32 p.m.)

Sapjeriani. 2018. Procedures for the elimination of regional property in the form of vehiclesoperational based on the Minister of Home Affairs number 19 of 2016 on the agency Jambi city financial and asset manager. (https://repository.unja.ac.id/4715/1/C0C0150310-ARTIKEL.pdf), (accessed February 06, 2020 at 11:55 am) 
Soemohadiwidjojo, T, Arini. 2014. Easy to Prepare SOP (Standard Operating Procedure. Jakarta: Penebur Plus.

Sugiyono. 2012. Quantitative, Qualitative and R\&D Research Methods. Bandung: Alphabet.

Law of the Republic of Indonesia Number 23 of 2014 concerning Regional Government.

Minister of Finance Regulation Number: 226/PMK.05/2016 concerning the Second Amendment to the Regulation of the Minister of Finance Number: 222/PMK.05/2014 Regarding Third Party Calculation Funds

Ratna, Amelia. 2017. Accounting Treatment of JKK JKM Contribution Income at PT TASPEN (Persero) Bandar Lampung Branch. (http://eprints.jeb.polinela.ac.id/296/1/Jurnal_Amelia\%20Ratna\%20Ramadhani.pdf) , (accessed February 5, 2020)

Romney, Marshall B. and Steinbart. 2015. "Accounting Information System 13th edition, transliterated: Kikin Sakinah Nur Safira and Novita Puspira". Jakarta : Salemba Empat

Sari, Hesty Puspita. et al. 2017. Application System for Processing Report Values at SDN Tanjunganom 2 Tanjunganom Nganjuk District. "Scientific Journal of Informatics Engineering". (Volumes 11:1).

Sudaryono. 2016. "Marketing Management". Yogyakarta: Andi Publisher

Suryani \& Hendryadi. 2015. "Quantitative Research Methods Theory and Applications in Research in the Field of Management and Islamic Economics". Jakarta: Prenada Media Group.

Widodo.2017. "Research Methodology, Popular \& Practical. Jakarta: PT Raja Grafindo Persada. 